\title{
Strategi Optimasi Penggunaan Antibiotik
}

\author{
Dina Fauzia*
}

\begin{abstract}
ABSTRAK
Use of antibiotics known is an important factor in the development of resistance tontibiotics, namely the use of antibiotics that are inappropriate, in the form of overuse or misuse. Inappropriate use of antibiotics should be reduced to prevent the selective pressure that will lead to the development of resistance to antibiotics. Given the magnitude of the problem of antibiotics use in hospitals and its impact on the growing and widespread resistance to antibiotics, it is necessary to immediately improve antibiotic use. Various strategies or interventions can be done at the hospital to optimize the provision of antibiotics.
\end{abstract}

Keywords: antibiotics, resistance, strategy, optimazing

Sejak masalah resistensi terhadap antibiotik mengemuka dan menjadi perhatian utama dunia, semua pihak yang terkait melakukan berbagai upaya untuk mengatasi masalah tersebut. Tahun 1998 World Health Organization (WHO) mengeluarkan suatu rekomendasi yang "mendesak" semua negara untuk segera menyusun pedoman nasional terapi antibiotik. Belakangan, pada 2001 WHO menetapkan enam strategi global untuk mengurangi masalah resistensi, yaitu (1) memperbaiki surveillance mikrobiologi, (2) memantau penggunaan obat, (3) meningkatkan ketepatan peresepan, (4) memberikan edukasi kepada profesional dan masyarakat, (5) meningkatkan pengendalian infeksi dan higiene, dan (6) mengajak industri farmasi untuk mengembangkan obat baru dan vaksin. ${ }^{1}$ Umumnya, keberhasilan pengendalian resistensi antibiotik akan dicapai dengan melakukan

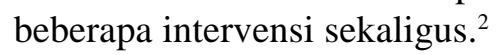

Berikut ini akan dibahas berbagai strategi yang dikembangkan untuk mencapai optimasi penggunaan antibiotik. Agar lebih sistematis, maka pembahasan akan dibagi menjadi 4 kelompok, yaitu (1) kebijakan antibiotik, (2) edukasi, (3)

\footnotetext{
* Penulis untuk korespondensi: Bagian Farmakologi Fakultas Kedokteran Universitas Riau. Jl. Diponegoro No. 1 Pekanbaru.

Email: dina_unrifk@yahoo.com
}

pemanfaatan technology support systems, dan (4) intervensi lain.

\section{Kebijakan Antibiotik}

\section{Antimicrobial Stewardship Programme (ASP)}

ASP adalah aktivitas yang dijalankan oleh institusi pelayanan kesehatan untuk mengoptimalkan penggunaan antimikroba pada pasien rawat inap. ASP merupakan program yang relatif baru yang meliputi ketepatan penggunaan antibiotik dalam hal pemilihan, dosis, cara pemberian, dan lama pemberian, dan diharapkan akan menjadi cara terbaik untuk mengendalikan penggunaan antibiotik di rumah sakit. Program ini mirip dengan program yang telah ada, seperti penerapan antibiotic policies, antibiotic management programs, antibiotic control programs. Bedanya, ASP dirancang lebih sistematis dan komprehensif. $^{3}$

ASP bertujuan mengoptimalkan hasil klinis (outcome) serta meminimalkan efek yang tidak diinginkan akibat penggunaan antibiotik yaitu toksisitas, seleksi organisme patogen, dan resistensi. Selain itu ASP juga bertujuan mengurangi biaya perawatan tanpa memberikan pengaruh negatif tehadap kualitas layanan, yaitu dengan mengurangi penggunaan antibiotik yang tidak tepat dan 
berlebihan, serta mendorong peralihan terapi intravena ke terapi oral. Kombinasi antara ASP yang efektif dengan program pengendalian infeksi yang komprehensif terbukti mampu membatasi perkembangan dan penyebaran bakteri yang resisten terhadap antibiotik. ${ }^{4-6}$

Manfaat yang diperoleh dari pelaksanaan ASP di rumah sakit adalah meningkatnya ketepatan pemberian antibiotik, yang meliputi tepat pemilihan, dosis, serta lama dan cara pemberian. ${ }^{5,6}$ Penerapan ASP yang efektif terbukti bermanfaat secara finansial dan memperbaiki kualitas perawatan pasien. Program yang komprehensif mampu mengurangi penggunaan antibiotik sebanyak 22\%$36 \%$ dan menghemat biaya sebesar \$200.000 $\$ 900.000$ baik di rumah sakit pendidikan besar ataupun rumah sakit umum yang lebih kecil..-6

Kendala utama dalam pelaksanaan ASP, yaitu dibutuhkan personel yang memiliki keinginan kuat dan kelapangan waktu untuk secara konsisten mengembangkan ASP. Kendala lain adalah keengganan anggota tim ASP untuk bersilang pendapat dengan kolega dari spesialisasi lain, menghilangkan otonomi dokter dalam membuat keputusan klinis, dan membutuhkan suatu kesinambungan yang perlu terus dimonitor dan dinilai pelaksanaan dan tingkat keberhasilannya. ${ }^{4-6}$

Terdapat beberapa intervensi yang dianjurkan dalam ASP dengan berbagai tingkat rekomendasi yang disusun oleh IDSA (Infectious Diseases Society of America). Pemilihan intervensi disesuaikan dengan pola penggunaan dan masalah resistensi antibiotik lokal/setempat, ketersediaan sumber daya yang bervariasi, serta kemampuan dan kondisi rumah sakit setempat. Anggota inti ASP terdiri dari dokter ahli penyakit infeksi dan farmasi klinik yang terlatih di bidang penyakit infeksi, spesialis mikrobilogi klinik, ahli sistem informasi, tenaga profesi pengendali infeksi, dan epidemiologis rumah sakit. ${ }^{4,6}$

Strategi inti dalam ASP adalah audit prospektif dengan intervensi dan umpan balik pada dokter pemberi resep. Strategi ini dilakukan oleh seorang dokter ahli penyakit infeksi atau seorang farmasi klinik yang terlatih di bidang penyakit infeksi. Keunggulan strategi ini adalah dokter tidak merasa kehilangan otonominya, apalagi bila saran perubahan dilakukan dengan sukarela/tanpa paksaan, dan juga memberikan pembelajaran berharga bagi klinisi. ${ }^{5,6}$ Penilaian ketepatan penggunaan antibiotik dilakukan setiap hari dan terbukti dapat mengurangi ketidaktepatan penggunaan antibiotik (A-I). ${ }^{4,5}$

Strategi kedua adalah pembatasan daftar obat dan preautorisasi. Strategi ini secara cepat dan bermakna dapat mengurangi penggunaan dan biaya antibiotik (A-II) dan juga bermanfaat dalam menindaklanjuti kejadian outbreak infeksi nosokomial (B-II). Namun, manfaat terhadap pengendalian resistensi terhadap antibiotik hingga kini masih kurang jelas karena secara jangka panjang dampaknya terhadap resistensi tidak terbukti. Bahkan, pada beberapa keadaan preautorisasi memunculkan resistensi baru terhadap antibiotik alternatif (B-II). Oleh karena itu, pada institusi yang menggunakan preautorisasi penting untuk selalu memonitor pola penggunaan antibiotik secara menyeluruh (B-III). ${ }^{4}$ Kelemahan utama dari strategi kedua ini adalah berkurangnya otonomi klinisi dalam membuat keputusan medis. Kelemahan lainnya adalah harus selalu tersedia tenaga konsultan sepanjang waktu dan dibutuhkan pembiayaan di awal untuk implementasi dan evaluasi program. ${ }^{5,6}$

Komponen pendukung bagi terlaksananya ASP yang efektif dan komprehensif, mencakup tiga aspek. Aspek pertama adalah ketersediaan teknologi informasi layanan kesehatan dalam bentuk catatan medik elektronik (A-III), computer physician order entry/CPOE (B-II), dan clinical decision support (BII). Dengan memasukkan berbagai data tiap pasien, seperti hasil kultur dan kepekaan kuman, fungsi ginjal dan hati, interaksi obat, alergi dan biaya, pemanfaatan teknologi informasi ini mampu memperbaiki keputusan pemberian antibiotik. Aspek kedua, laboratorium mikrobiologi yang menyediakan informasi kultur dan sensitivitas untuk tiap pasien (A-III). Aspek ketiga, proses monitoring dan pengukuran hasil untuk mengetahui dampak ASP terhadap penggunaan antimikroba dan pola resistensi (B-III). ${ }^{4}$ Sejak September 2006, sembilan negara di Eropa menerapkan ASP yang menggunakan beberapa perangkat yaitu daftar antibiotik, pedoman penggunaan antibiotik, pedoman profilaksis bedah, alat penganalisis konsumsi antibiotik dan organisasi pendukung 
pengendalian antibiotik (antibiotic officer dan tim manajemen antibiotik). ${ }^{7}$

\section{Penyusunan Formularium (Antibiotik)}

Formularium antibiotik merupakan daftar sederhana obat yang tersedia untuk digunakan di suatu rumah sakit. Pengendalian formularium efektif mempengaruhi peresepan antibiotik sekaligus dapat mengurangi penggunaan dan resistensi terhadap antibiotik. Selain itu, metode ini tidak menimbulkan dampak/efek negatif terhadap pasien, serta memberikan edukasi positif pada dokter pemberi resep. ${ }^{8}$ Standar yang harus dipegang dalam menyusun dan menerapkan formularium antibiotik adalah sebagai berikut. ${ }^{8}$

a. Antibiotik yang akan dimasukkan ke dalam formularium dipilih terutama berdasarkan bukti efikasi. Pertimbangan lain terkait dengan kelebihan yang dimiliki oleh suatu antibiotik, seperti tidak mudah mengalami resistensi, profil baik secara farmakokinetik dan farmakodinamik, efek samping minimal, dan relatif murah. Sebaiknya dihindari duplikasi antibiotik sehingga efisien dalam pengadaannya.

b. Pemilihan antibiotik mengacu pada pola kepekaan kuman setempat.

c. Antibiotik disusun menurut pembatasan penggunaanya, dimulai dari antibiotik yang dapat digunakan secara luas hingga antibiotik yang hanya dapat diresepkan untuk indikasi tertentu.

d. Formularium harus direvisi secara berkala untuk mengeluarkan antibiotik yang sudah tidak efektif berdasarkan pola kepekaannya dan memasukkan antibiotik yang dipandang diperlukan.

e. Compliance terhadap penerapan formularium diaudit secara rutin.

\section{Restriksi Antibiotik}

Restriksi atau pembatasan jenis antibiotik atau kelas antibiotik dalam formularium rumah sakit telah diakui sebagai salah satu strategi untuk mengurangi kejadian resistensi antibiotik, menekan biaya antibiotik, serta menurunkan pemakaian berlebihan antibiotik spektrum luas secara empiris. ${ }^{2}$ Hasil studi besar menunjukkan bahwa restriksi antibiotik mampu menurunkan 32\% kebutuhan antibiotik parenteral, sekaligus meningkatkan kembali kepekaan patogen tanpa diikuti dengan dampak buruk terhadap outcome klinis, survival dan lama rawat di rumah sakit. ${ }^{9}$

Secara umum, antibiotik yang harus dibatasi penggunaannya di rumah sakit adalah antibiotik berspektrum luas (mis. karbapenem), antibiotik yang mudah mengalami resistensi (mis. sefalosporin) dan antibiotik yang mudah menimbulkan toksisitas (mis. aminoglikosida). Namun, hal tersebut sulit untuk diterapkan sehingga pembatasan antibiotik sebaiknya berdasarkan data kejadian outbreak resistensi terhadap antibiotik tertentu yang diperoleh dari survei berkala dan laporan dari laboratorium mikrobiologi. ${ }^{2,10}$

Dengan pembatasan formularium, antibiotik dibedakan menjadi dua, yaitu unrestricted dan restricted antibiotics. Antibiotik unrestricted dapat diresepkan oleh tiap dokter tanpa perlu meminta persetujuan sebelumnya, sedangkan restricted antibiotics hanya boleh diresepkan atas dasar pedoman yang disusun oleh Panitia Pengendalian Antibiotik atau setelah melalui diskusi dengan "pakar" yang telah ditunjuk. ${ }^{8}$

Keberhasilan penerapan restriksi formularium sangat bergantung pada tingkat kepatuhan (compliance) dokter terhadap formularium tersebut. Terdapat dua metode untuk meningkatkan compliance terhadap formularium. Metode pertama, mengharuskan pemberi resep menggunakan formulir permintaan antibiotik untuk antibiotik yang penggunaannya dibatasi. Formulir tersebut harus dilengkapi dengan beberapa informasi, yaitu indikasi penggunaan (profilaksis, empiris, atau definitif), tempat infeksi, kriteria klinis dalam menegakkan diagnosis infeksi, patogen yang diduga atau telah dikonfirmasi sebagai penyebab infeksi, informasi menyangkut pasien (usia, berat badan, penyakit dasar, fungsi hepar dan ginjal, riwayat alergi), dan informasi menyangkut antibiotik (dosis, frekuensi dan cara pemberian, lama pemberian). Masalah dalam penerapan metode ini adalah dibutuhkan dukungan sistem informasi berbasis teknologi. Selain itu, sulit untuk dokter pemberi resep melengkapi begitu banyak informasi yang dibutuhkan sehingga kualitas informasi yang diperoleh menjadi tidak memadai (inadequat). Di 
Inggris, kebanyakan rumah sakit tidak memiliki sumber daya yang cukup untuk melaksanakan metode ini sehingga cara ini dianggap tidak praktis (impracticable). ${ }^{8}$

Metode kedua adalah pemberlakuan persyaratan berupa persetujuan dari "pakar" untuk menggunakan antibiotik yang restricted. Persetujuan ini umumnya diminta dari seorang ahli mikrobiologi klinik atau dokter dari divisi penyakit infeksi. Idealnya, persetujuan dapat diberikan di dalam ataupun di luar jam kerja. Selama jam kerja, farmasis akan mengirim resep permintaan tersebut kepada dokter mikrobiologi klinik atau dokter dari divisi penyakit infeksi, selanjutnya didiskusikan dengan dokter penulis resep, lalu persetujuan (approval) dapat diberikan, atau disarankan untuk menggunakan regimen alternatif. Di luar jam kerja, maka maksimal dalam waktu yang ditentukan (biasanya 24-48 jam), farmasis yang bertugas terakhir harus meminta tenaga ahli lokal untuk menyetujui atau menolak permintaan resep tersebut. $^{8}$

Masalah yang berhubungan dengan restriksi antibiotik adalah meningkatnya resistensi terhadap antibiotik yang tidak dibatasi penggunaannya. Oleh karena itu, saat ini restriksi antibiotik dijalankan hanya bila terjadi ledakan (outbreak) infeksi yang disebabkan oleh suatu patogen yang resisten terhadap antibiotik tertentu atau jika pengendalian infeksi lainnya tidak berhasil. ${ }^{2}$

\section{Guidelines Penggunaan Antibiotik}

Guidelines klinis penggunaan antibiotik sangat dibutuhkan sebagai instrumen yang efektif untuk menghindari pemberian antibiotik yang tidak perlu sekaligus juga untuk meningkatkan efektivitas antibiotik yang diresepkan. Penelitian terbaru menunjukkan bahwa penerapan guidelines tersebut secara dramatis memberikan manfaat yang bermakna dalam menghentikan kejadian resistensi terhadap antibiotik. ${ }^{2,10}$

Pedoman penggunaan antibiotik makin popular digunakan di berbagai pelayanan kesehatan karena terbukti mampu mempengaruhi kebiasaan dalam memberikan resep. Pada survei terhadap sejumlah dokter di Inggris pada tahun 1994, diperoleh data $62 \%$ responden mengatakan bahwa rumah sakit tempat mereka bekerja menggunakan pedoman peresepan antibiotik. Sementara, survei serupa di Amerika Serikat tahun 1998 mendapati hasil sebesar $70 \%{ }^{8}$

Beberapa hal berikut ini penting diperhatikan dalam menyusun pedoman antibiotik:

a. harus dibedakan pedoman peresepan antibiotik untuk profilaksis, empiris, dan definitif;

b. melibatkan tenaga ahli multidisipilin (sekitar 610 orang) dalam penyusunannya, termasuk dokter dari berbagai spesialisasi terkait dan seorang yang mampu melakukan pencarian literatur dan systematic reviews;

c. masukan pendapat dari stakeholder atau calon pengguna dipertimbangkan sehingga memudahkan implementasi pedoman nantinya;

d. tim penyusun mencari pedoman yang sudah ada untuk suatu topik tertentu, dan selanjutnya mengambil dan menyesuaikannya dengan kondisi setempat;

e. pedoman disusun berdasarkan systematic review dan bukti ilmiah, dan selanjutnya bukti ilmiah tersebut disusun sesuai dengan tingkat rekomendasi dan kekuatannya;

f. antibiotik yang dipilih selaras dengan pola patogen dan sensistivitas lokal dan dilengkapi dengan informasi mengenai dosis, lama dan cara pemberian, penyesuaian dosis pada gangguan fungsi ginjal, serta antibiotik alternatif jika pasien alergi terhadap antibiotik lini pertama;

g. pedoman antibiotik penggunaan profilaksis sebaiknya mengatur secara spesifik indikasi antibiotik untuk suatu prosedur tertentu, pilihan optimal, dosis, waktu pemberian, serta cara dan lama pemberiannya;

h. setelah selesai disusun, pedoman dinilai oleh kelompok lain di luar tim penyusun yang memiliki keahlian di bidang terkait;

i. secara periodik (misalnya tiap dua tahun) pedoman diperbarui dengan mengacu pada kemajuan pengetahuan medis, perubahan praktek klinis dan kondisi lokal, serta hasil evaluasi implementasi pedoman terdahulu;

j. pedoman antibiotik sebaiknya tidak terlalu panjang (tidak lebih dari 20-25 halaman), 
sederhana, tidak kontroversial, relevan secara klinis, fleksibel, aplikatif, dibuat dalam format yang mudah digunakan.

Pedoman antibiotik dapat disusun untuk tingkat nasional maupun lokal, masing-masing dengan keunggulan dan kelemahannya.,

(a) Pedoman lokal umumnya kurang ilmiah dibandingkan dengan pedoman nasional karena tim lokal biasanya memiliki kelemahan secara klinis, manajerial, dan teknis, belum lagi kendala biaya dan waktu;

(b) Dalam penyusunannya, pedoman lokal seringkali memasukkan pendapat ahli yang menimbulkan bias dalam pengambilan keputusan klinis;

(c) Pedoman nasional sering bermasalah dalam implementasinya karena para klinisi enggan menggunakannya pedoman yang disusun oleh "pakar" yang tidak mereka kenal; mereka menunjukkan ketidaksetujuan atau ketidakpercayaannya terhadap pedoman yang telah disusun tersebut;

(d) Dengan demikian dibutuhkan lebih sedikit upaya dalam penyebarluasan dan penerapan pedoman lokal, sebaliknya pedoman nasional harus berusaha lebih kuat untuk bisa menyebarluaskan informasi dan melakukan tindakan persuasif untuk implementasi pedoman;

(e) Pedoman lokal dinilai lebih unggul dibandingkan dengan pedoman nasional karena lebih mencerminkan kondisi setempat yang disesuaikan dengan pola dan sensitivitas kuman di rumah sakit setempat. Selain itu, serta pedoman lokal lebih diterima baik oleh penggunanya.

Hal penting lain yang juga perlu diperhatikan adalah mengenai implementasi pedoman, yang merupakan proses untuk memastikan bahwa guidelines tersebut diterapkan dalam praktek klinis. Survei memperlihatkan angka antara 20\% hingga $>90 \%$ untuk compliance terhadap suatu pedoman, tergantung sifat pedoman, masalah klinis yang dituju, pasien target, jenis/bentuk implementasi, dan batasan yang dianut untuk definisi "adherence". Kenyataan dalam praktek, klinisi yang paling berpengalaman umumnya justru yang paling tidak patuh terhadap pedoman. Cabana dkk (1999) menemukan beberapa hal yang menjadi penghalang (barier) implementasi pedoman, yaitu ketidaktahuan mengenai adanya pedoman, sikap (kurang setuju dengan pedoman, tidak percaya pada pedoman, kurang percaya diri, atau kelemahan/kesalahan pada praktek terdahulu). Kondisi lain yang menyebabkan klinisi enggan menerapkan pedoman adalah karena pedoman itu dirasakan tidak cocok untuk praktek klinis. Hal ini dapat karena pedoman kurang valid secara ilmiah, tidak melibatkan stakeholder penting saat penyusunannya, atau karena alasan nonklinis seperti tidak mendapat imbalan jika menerapkan pedoman, takut dituntut secara hukum, opini dokter lokal yang tidak mendukung, dan inefisiensi sistem pelayanan kesehatan. Dokter residen yang bukan merupakan pembuat keputusan dalam peresepan obat (termasuk antibiotik) juga menjadi penghalang di rumah sakit pendidikan. Berdasarkan hal tersebut, faktor penghalang penerapan guidelines dapat dikelompokkan menjadi 3, yaitu yang berhubungan dengan pedomannya, karakter dokter, dan kondisi sosial dan institusi. Seharusnya suatu pedoman dapat memberikan perubahan pada praktek klinis dengan cara mengubah pengetahuan, perilaku, dan keyakinan klinikus. ${ }^{8,11-12}$

Pedoman yang baik tidak otomatis dapat diterapkan dengan baik karena sangat bergantung pada kepatuhan (compliance) penggunanya, dalam hal ini adalah dokter. Mol, dkk (2004) melaporkan compliance yang masih di tingkat low-moderate (40$60 \%)$ sehingga perlu terus ditingkatkan. ${ }^{11}$

Cara yang dapat digunakan untuk meningkatkan kepatuhan terhadap pedoman adalah mencari dukungan organisasi profesi lokal dan nasional, menyatukan ke dalam praktek klinis oleh "expert" klinis setempat, diseminasi pedoman oleh kepala departemen, audit kepatuhan terhadap guidelines dengan memberikan umpan balik hasil kepada klinisi, menggunakan alat pengingat untuk tiap pasien misalnya dengan mengintegrasikan pedoman dengan rekam medik atau dengan alat pengingat umum, menggabungkan guidelines ke program pengambilan keputusan klinis menggunakan komputer, melibatkan pengguna penting guidelines saat proses penyusunannya, menggabungkan guidelines ke dalam perjanjian kerja sama antara pihak pembayar (asuransi) dengan pemberi pelayanan (rumah sakit atau klinisi), atau dengan program academic detailing secara perorangan. ${ }^{8}$ 
Penggunaan salah satu atau kombinasi metode tersebut di atas mampu meningkatkan kepatuhan terhadap guidelines dalam tingkat yang berbeda. Dari banyak studi terbukti bahwa penggunaan beberapa intervensi lebih efektif dibandingkan hanya dengan intervensi tunggal. ${ }^{8}$

Implementasi suatu pedoman membutuhkan diseminasi (penyebarluasan). Terbukti salah satu alasan tidak efektifnya guidelines adalah ketidaktahuan klinisi mengenai keberadaan pedoman. Dengan diseminasi, kepedulian klinisi terhadap guidelines dapat ditingkatkan sehingga berpengaruh pada pengetahuan, sikap dan perilaku mereka. Cara yang bisa ditempuh untuk diseminasi adalah publikasi melalui jurnal, news, pelaporan, atau dokumen lokal, handbook dokter junior, poster di bangsal perawatan dan departemen terkait, program pendidikan, dan kunjungan perorangan. Hingga kini belum dapat ditentukan strategi optimal untuk diseminasi pedoman. Publikasi di jurnal merupakan cara yang paling sering dilakukan, meskipun hasilnya sering kurang memuaskan. Mengirimkan email ke para klinisi terlihat lebih efektif, meskipun efikasinya juga terbatas. Secara umum, intervensi secara pasif dianggap sebagai cara diseminasi yang kurang memuaskan dan hanya menimbulkan perubahan perilaku sesaat/sementara. Grishaw dan Russel (1994) mengklaim bahwa strategi diseminasi guidelines yang paling efektif adalah melalui jalur pendidikan (misalnya seminar) karena berpotensi kuat untuk diadopsi dan dampaknya lebih bertahan lama. ${ }^{8}$

Suatu pedoman juga perlu dinilai manfaatnya dalam menimbulkan perubahan dalam praktek klinis dan outcome klinis. Audit adalah cara yang paling efektif untuk menilai manfaat penerapan pedoman, namun selayaknya evaluasi dilakukan untuk semua komponen proses penerapan guidelines, tidak hanya outcome. Artinya, perbaikan outcome klinis tidak dapat dijadikan sebagai patokan tunggal untuk menilai keberhasilan penerapan pedoman. Harus dipastikan bahwa guidelines tersebut benar telah diterima, dibaca dan dipakai oleh klinisi. ${ }^{8}$

\section{Program Pendidikan (Edukasi)}

Program edukasi dirancang untuk meningkatkan pemahaman dokter mengenai resistensi terhadap antimikroba dan ketepatan penggunaan antimikroba. Program ini relatif murah dan mudah untuk diterapkan di rumah sakit, tetapi sulit membuktikan korelasi antara keberhasilan edukasi dengan penurunan resistensi antimikroba. Pengaruh program dibatasi oleh kurangnya dukungan institusi sehingga biasanya pengaruhnya hanya bertahan dalam waktu singkat, apalagi bila dijalankan sebagai program tunggal. ${ }^{13}$ Oleh karena itu, banyak institusi menambahkan program edukasi pada antimicrobial stewardship program atau intervensi aktif lainnya. Bersama dengan program lainnya edukasi mampu memberikan perubahan bermakna. Edukasi dijadikan sebagai program dasar dalam upaya optimasi penggunaan antibiotik di banyak rumah sakit dengan tujuan mengubah prescribing behavior, sekaligus memberikan dasar keilmuan yang akan meningkatkan penerimaan klinikus terhadap strategi stewardship program. ${ }^{4,13}$

Agar efek terhadap pola peresepan dapat dipertahankan, maka sikap dan keyakinan dokter perlu diubah dengan menerapkan beberapa intervensi lain, seperti audit dan feedback, computerassisted decision support, intervensi dengan media massa, dan materi edukasi yang dicetak. Strategi jangka panjang yang lebih efektif untuk membentuk pola peresepan adalah dengan melakukan intervensi terhadap calon dokter (mahasiswa kedokteran). ${ }^{8}$

\section{Pemanfaatan Technology Support Systems}

\section{Computer Order Entry}

Computer order entry mampu memperbaiki kebiasaan dokter meresepkan antibiotik. Metode ini juga memberikan informasi mengenai indikasi pemberian antibiotik dan pilihan antibiotiknya, dan dapat dilengkapi dengan informasi pola resistensi lokal. Dalam sistem yang lebih canggih, informasi hasil pemeriksaan mikrobiologi dan pemeriksaan lainnya dimasukkan juga ke dalam algoritme pengambilan keputusan peresepan antibiotik sehingga proses peresepan antibiotik didukung oleh informasi yang lengkap. Informasi ini dianggap bersifat netral, tidak menggurui/memaksa (dokter tidak merasa kehilangan otonominya), efisien dan diterima baik, dan dapat mengubah pola peresepan secara dramatis. ${ }^{9}$

Rancangan program komputer ini disesuaikan dengan kebutuhan dan kemampuan institusi 
pelayanan kesehatan. Suatu rumah sakit pendidikan tersier di Australia menyusun program yang dinamakan "IDEA3S" (infectious diseases electronic antibiotic advice and approval system). program ini bertujuan memberikan persetujuan antibiotik secara cepat melalui komputer untuk sejumlah indikasi lazim yang evidence-based, sekaligus menjaga ketepatan pemberian antibiotik. Metode ini dianggap praktis secara klinis, mudah diterima oleh klinikus, dan efisien. Keberhasilannya tidak terlepas dari kerja sama yang baik di antara klinikus, farmasis dan tenaga administratif rumah sakit, bersamaan dengan edukasi pada klinikus dan melakukan feedback hasil. ${ }^{14}$

\section{Kebijakan “Automatic Antibiotic Stop-Order”}

Kebijakan ini bertujuan membatasi lama penggunaan antibiotik. Dalam bentuk yang paling sederhana, kebijakan ini meminta dokter pemberi resep secara spesifik menetapkan lama penggunaan tiap antibiotik yang diresepkannya. Secara teori, seharusnya hal ini dapat dilakukan sendiri oleh dokter. Namun, kenyataannya sulit menumbuhkan kesadaran sendiri, sehingga perlu diingatkan atau bahkan sedikit dipaksakan agar kebijakan efektif. Farmasis diberi tanggung jawab untuk menghentikan resep yang masih dituliskan melewati periode yang telah disepakati, biasanya antara 48 hingga 72 jam. Dua puluh empat jam sebelum tanggal penghentian antibiotik, dokter diingatkan agar terapi tidak berkelanjutan. Jika suatu antibiotik masih akan diteruskan pemberiannya, maka dokter harus meresepkannya kembali, meskipun resep tersebut mungkin saja ditolak. Idealnya, sebelum menerapkan kebijakan tersebut, perlu dibuat suatu program pendidikan/pelatihan bagi dokter mengenai penggunaan antibiotik. ${ }^{8}$

Kebijakan "automatic stop-order" dinilai efektif dalam menjamin pemberian antibiotik sehingga tidak berkepanjangan penggunaannya. Masalah yang muncul dengan kebijakan ini adalah pasien berpotensi terlalu singkat mendapat antibiotik. Komputerisasi dalam peresepan ini dapat mencegah konflik langsung dengan dokter yang distop permintaan resepnya. ${ }^{8}$

Variasi lain dari kebijakan "stop-order" adalah pre-printed antibiotic prescription/order form. Dalam kebijakan ini, dokter pemberi resep harus menjelaskan indikasi permintaan antibiotik sebagai profilaksis, empiris, atau definitif. Bila indikasi antibiotik untuk profilaksis, maka secara administratif resep akan dihentikan setelah 24 jam. Bila peresepan antibiotik dimasudkan sebagai terapi empiris, maka resep akan dihentikan setelah 48-72 jam. Dokter kemudian akan menilai ulang kebutuhan antibiotik dan ketepatan regimen antibiotik berdasarkan informasi klinis yang baru, seperti hasil pemeriksaan laboratorium atau pencitraan (radiologis) yang seharusnya telah tersedia. Dan, bila antibiotik tersebut ditujukan untuk terapi definitif, maka lama pemberiannya 57 hari. $^{8}$

\section{Intervensi Lain}

\section{Streamlining (Efisiensi Terapi)}

Streamlining adalah konversi terapi antibiotik inisial dari regimen spektrum luas ke spektrum sempit, dari terapi kombinasi ke monoterapi, atau dari obat baru dan mahal ke obat lama dan lebih murah dengan efektivitas yang sebanding. Efisiensi terapi dilakukan dengan mengacu pada hasil kultur dan sensitivitas kuman serta respons klinis pasien. Meskipun masih sedikit bukti yang menunjukkan efektivitas streamlining, pengalaman di beberapa institusi menyatakan bahwa intervensi ini dapat diterapkan, efektif dan aman. ${ }^{8}$

Manfaat melakukan efisiensi terapi antara lain dapat menghemat biaya, mengurangi insidens toksisitas, dan mengurangi selective pressure. Selain itu juga memberikan edukasi bagi dokter. ${ }^{4,8}$

\section{Peralihan (switching) Terapi Parenteral ke Oral}

Peralihan antibiotik parenteral ke oral, juga dikenal sebagai terapi antibiotik sekuensial, dan merupakan salah satu bentuk efisiensi terapi. Regimen oral dapat berupa antibiotik yang sama dengan bentuk formulasi oral atau antibiotik dari kelas berbeda. Yang terpenting, regimen oral yang memiliki efikasi sebanding dengan regimen parenteral dan memiliki bioavailibilitas oral yang baik. Biasanya, konversi dilakukan berdasarkan beberapa kriteria yang lazim dianut. ${ }^{8}$

Terapi oral memiliki beberapa keunggulan, yaitu lebih mudah diberikan, relatif lebih murah, 
insidens komplikasi (akibat pemberian obat intravena) lebih rendah, lama rawat di rumah sakit lebih singkat, dan risiko pasien terpapar/ tertular patogen resisten juga lebih rendah., ${ }^{4,9}$ Permasalahan yang berhubungan dengan penerapan switching adalah dibutuhkan kerjasama dari tim dokter, farmasi rumah sakit, ahli mikrobiologi dan para petugas kesehatan lain. ${ }^{8}$

\section{Terapi Kombinasi Antibiotik}

Manfaat terapi kombinasi antibiotik untuk infeksi oleh $M$. tuberculosis sudah tidak diragukan lagi. Namun, masih sedikit bukti keberhasilan terapi kombinasi antibiotik untuk kasus infeksi oleh bakteri lain. Keberhasilan terapi kombinasi antibiotik telah dibuktikan di Denmark. Dari 8840 isolat bakteremia yang dikumpulkan selama 10 tahun, enterobakter memperlihatkan tingkat resistensi yang sangat rendah $(<1 \%)$ terhadap sefalosporin generasi-3, karbapenem, aminoglikosida, dan fluorokuinolon. Ternyata hasil tersebut merupakan dampak terapi empiris menggunakan kombinasi penisilin $\mathrm{G}$ atau ampisilin dan aminoglikosida yang cakupannya mencapai 94\%. Beberapa peneliti juga memperoleh manfaat terapi kombinasi antibiotik di ICU, berupa angka kesembuhan secara bakteriologis yang lebih tinggi pada pasien dengan infeksi nosokomial dibandingkan dengan menggunakan regimen monoterapi. ${ }^{2,15}$

Secara umum, hingga kini belum cukup bukti yang mendukung pelaksanaan terapi kombinasi secara rutin untuk kasus infeksi (selain antituberkulosis dan antiretroviral), khususnya dalam meminimalkan ancaman resistensi terhadap antibiotik. ${ }^{4,8}$

\section{Rotasi (cycling) Antibiotik}

Rotasi antibiotik merupakan kegiatan berkala menarik penggunaan suatu kelas antibiotik (atau satu antibiotik tertentu) dan menggantinya dengan kelas antibiotik yang lain. ${ }^{16}$ Rotasi dilakukan atas dasar pemikiran bahwa makin sering suatu antibiotik diresepkan, maka makin besar kemungkinan terjadinya resistensi. Sehingga, dengan menghentikan pemakaian suatu antibiotik untuk jangka waktu tertentu diharapkan akan mengurangi selective pressure dan nantinya akan mengembalikan sensistivitas terhadap antibiotik tersebut. $^{8}$

Jenis antibiotik yang akan dirotasi dan periode tiap rotasi ditetapkan berdasarkan pola kuman dan sensitivitas lokal. ${ }^{16}$ Hingga kini belum ada standar periode tiap rotasi sehingga tiap institusi menggunakan periode yang berbeda. Rotasi antibiotik paling efektif jika diterapkan pada suatu lingkungan/unit tertutup, misalnya ICU atau unit luka bakar. ${ }^{8,16-18}$

Rotasi antibiotik dibedakan menjadi 2 bentuk berdasarkan cara pelaksanaannya, yaitu proactive swithcing dan reactive switching. Pada proactive switcing, rotasi antibiotik dilakukan sebelum munculnya resistensi terhadap antibiotik, dan merupakan metode rotasi antibiotik yang benar. Sebaliknya, reactive switching dilakukan sebagai reaksi terhadap peningkatan resistensi terhadap antibiotik yang telah/sedang berlangsung. ${ }^{18}$

Permasalahan pada rotasi antibiotik adalah rendahnya kepatuhan dokter terhadap protokol rotasi. Penyebab ketidakpatuhan antara lain, dokter sering mengabaikan protokol dan tetap meresepkan antibiotik yang berada di luar rotasi, dan alergi atau toksisitas menghalangi pemakaian antibiotik yang ada di dalam rotasi. ${ }^{7}$

Rotasi antibiotik merupakan metode intervensi yang relatif baru, sehingga data yang mendukung keberhasilannya masih sangat terbatas. ${ }^{16}$ Suatu hasil studi menggunakan model matematika menyatakan bahwa rotasi akan selalu lebih inferior daripada penggunaan antibiotik “campuran” (peresepan berbagai antibiotik dari kelas berbeda secara simultan) pada tingkat populasi. ${ }^{19}$ Oleh karena itu, hingga kini rotasi antibiotik belum dapat diterima secara umum sebagai strategi yang dapat mengurangi ancaman perkembangan resistensi terhadap antibiotik di rumah sakit. ${ }^{18}$ Selain itu, penerapan rotasi untuk semua indikasi pemakaian antibiotik cukup sulit untuk diterapkan, sehingga saat ini rotasi hanya dibatasi untuk penggunaan empiris. ${ }^{9}$

\section{KESIMPULAN}

1. Resistensi terhadap antibiotik menjadi masalah yang terus meningkat di seluruh dunia dan membuat kekhawatiran bagi semua pihak karena 
sangat berpotensi untuk mengalami "postantibiotic era".

2. Resistensi terhadap antibiotik merupakan akibat penggunaan antibiotik yang tidak tepat, sehingga perlu dilakukan upaya optimasi penggunaan antibiotik.

3. Dampak resistensi terhadap antibiotik berupa peningkatan morbiditas dan mortalitas penyakit infeksi, pemanjangan masa perawatan di rumah sakit, dan peningkatan biaya perawatan/ pengobatan.

4. Penggunaan antibiotik yang optimal mencakup 2 aspek, yaitu mengurangi penggunaan yang tidak perlu/"less use" dan meningkatkan ketepatan pemakaiannya/"appropriate use" (tepat pilihan, dosis, cara pemberian dan lama pemberian).

5. Beberapa strategi yang dikembangkan untuk mencapai optimasi penggunaan antibiotik adalah: (1) menyusun kebijakan antibiotik (2) memberikan edukasi, (3) memanfaatkan technology support systems, dan (4) intervensi lain.

6. Keberhasilan pengendalian resistensi terhadap antibiotik dicapai melalui optimasi penggunaannya menggunakan beberapa intervensi secara simultan.

\section{DAFTAR PUSTAKA}

1. Tillotson GS. Antibiotic resistance: opportunity or obstacle for the pharmaceutical industry?. In: Owens RC, Lautenbach E, ed. Antimicrobial resistance: problem pathogens and clinical countermeasures. USA: Informa healthcare, 2007.

2. Kollef MH. Optimizing antibiotic therapy in the intensive care unit setting. Critical Care 2001;5:189-95.

3. MacDougall C, Polk RE. Antimicrobial stewardship programs in health care systems. Clinical Microbiology Reviews 2005;18:638-56.

4. Dellit TH, Owens RC, McGowan JE, Gerding DN, Weinstein RA, Burke JP, et al. Infectious Diseases Society fo Healthcare Epidemiology of America Guidelines for developing an institutional program to enhance antimicrobial stewardship. Clinical Infectious Diseases 2007;44:159-77.

5. Drew RH. Antimicrobial Stewardship Programs: How to Start and Steer a Successful Program. $J$ Manag Care Pharm 2009;15(2):S18-S23.

6. MacDougall C, Polk RE. Antimicrobial stewardship programs in health care systems. Clinical Microbiology Reviews 2005;18:638-56.

7. Allerberger F, Lechner A, Wechsler-Fordos A, Gareis R. Optmization of antibiotic use in hospitals-antimicrobial stewardship and the EU project ABS international. Chemotherapy 2008;54:260-7.

8. Brown EM. Intervention to optimise antibiotic prescribing in hospitals: the UK approach. In: Gould IM, Meer JWM, ed. Antibiotic policies: theory and practice. New York, Kluwer Academic/Plenum Publishers, 2005.

9. Weinstein RA. Controlling antimicrobial resistance in hospitals: infection control and use of antibiotics. Emerging Infectious Diseases 2001;7(2):188-92.

10.Kollef MH. Bench-to-bedside review: Antimicrobial utilization strategies aimed at preventing the emergency of bacterial resistance in the intensive care unit. Critical Care 2005;9:459-64.

11.Mol PGM, Weiringa JE, NannanPanday PV, Gans ROB, Degener JE, Laseur M, et al. Improving compliance with hospital antibiotic guidelines: a time-series intervention analysis. Journal of Antimicrobial Chemotherapy 2005;55:550-7.

12.Mol PGM, Rutten WJM, Gans ROB, Degener JE, Haaijer-Ruskamp FM. Adherence barriers to antimicrobial treatment guidelines in teaching hospital, the Netherlands. Emerging Infectious Diseases 2004;10(3):522-5.

13.Paterson DL. The role of antimicrobial management programs in optimizing antibiotic prescribing within hospitals. Clinical Infectious Diseases 2006;42:S90-5.

14.Grayson ML, Melvani S, Kirsa SW, Cheung S, Korman AM, Garrett MK, et al. Impact of an 
electronic antibiotic advice and approval system on antibiotic prescribing in an Australian teaching hospital. MJA 2004;180:455-8.

15.D’Agata EMC, Dupont-Rouzeyrol M, Magal P, et al. The impact of different antibiotic regimens on the emergence of antimicrobial-resistant bacteria. PloS One. 2008;3(12):e4036:1-9.

16.Brown EM, Nathwani D. Antibiotic cycling or rotation: a systematic review of the evidence of efficacy. Journal of Antimicrobial Chemotherapy 2005;55:6-9.
17.Lim V. Control of antimicrobial resistance in the hospital: strategies for antimicrobial use. ISAAR 2003;95-8.

18.Camins BC, Fraser VJ. Antimicrobial cycling programs. In: Owens RC, Lautenbach E, ed. Antimicrobial resistance: problem pathogens and clinical countermeasures. USA, Informa healthcare, 2007.

19.Bergstrom CT, Lo M, Lipsitch M. Ecological theory suggests that antimicrobial cycling will not reduce antimicrobial resistance in hospitals. Proc Natl Acad Sci USA 2004;101(36):1328590. 